\title{
PENGARUH ECONOMIC VALUE ADDED DAN FREE CASH FLOW TERHADAP STOCK PRICE
}

\author{
Stefany Tantri dan Yusbardini \\ Program Studi Manajemen/Akuntansi Fakultas Ekonomi Universitas Tarumanagara, Jakarta \\ Email: stefany.115170166@stu.untar.ac.id
}

Abstract: The purpose of this study is to examine the effect of economic value added and free cash flow in manufacturing sector consumer industry in Indonesian Stock Exchange on period 2015-2019. The sample of this study are 31 company with purposive sampling method. Data were collected by official website of Indonesian Stock Exchange. The data will be analysis by using Eviews9 application. The result found that economic value added have significant effect to stock price, free cash flow have significant effect to stock price and economic value added and free cash flow simultaneously have significant effect to stock price.

Keywords: Economic Value Added, Free Cash Flow, Stock Price.

Abstrak: Tujuan dari penelitian ini adalah untuk mengetahui pengaruh nilai tambah ekonomis dan arus kas bebas pada perusahaan manufaktur sektor industri barang konsumsi di Bursa Efek Indonesia periode 2015-2019. Sampel dari penelitian ini adalah 31 perusahaan dengan metode purposive sampling. Data perusahaan diperoleh dari website resmi Bursa Efek Indonesia. Data dianalisis menggunakan aplikasi Eviews9. Hasil penelitian ini menemukan bahwa nilai tambah ekonomis mempunyai pengaruh yang signifikan terhadap harga saham, arus kas bebas mempunyai pengaruh yang signifikan terhadap harga saham, dan nilai tambah ekonomis dan arus kas bebas secara simultan mempunyai pengaruh yang signifikan terhadap harga saham.

Kata Kunci: Nilai Tambah Ekonomis, Arus Kas Bebas, Harga Saham.

\section{LATAR BELAKANG}

Pasar modal berperan penting bagi seorang investor dan perusahaan. Banyaknya perusahaan yang menerbitkan berbagai sekuritas di pasar modal dapat meningkatkan ketertarikan seorang investor untuk berinvestasi. Melalui pasar modal, seorang investor dapat memperoleh keuntungan atau return yang tinggi dengan melakukan pembelian saham pada perusahaan tertentu. Untuk memperoleh keuntungan dari penginvestasian tersebut, hal yang harus diperhatikan oleh seorang investor yaitu dengan melihat kinerja keuangan perusahaan tersebut. Fluktuasi harga saham dapat dilihat dari kinerja keuangan perusahaan. Harga saham merupakan cerminan atau gambaran yang dapat digunakan oleh seorang investor untuk melihat kinerja keuangan perusahaan tersebut karena jika kinerja keuangan perusahaan meningkat maka harga saham akan meningkat sebaliknya dengan kinerja keuangan perusahaan yang menurun maka harga saham akan menurun. Maka dari itu, setiap perusahaan ditugaskan untuk mempertahankan kinerja keuangan perusahaannya dikarenakan hal tersebut merupakan hal penting yang dapat digunakan oleh seorang investor untuk melakukan kegiatan investasi atau penanaman modal pada perusahaan tersebut. 
Salah satu metode yang dapat digunakan untuk mengukur kinerja keuangan selain menggunakan rasio keuangan yaitu dengan menggunakan metode Economic Value Added (EVA). EVA dapat digunakan dengan mengukur suatu laba operasional setelah pajak yang telah dikurang oleh biaya modal perusahaan yang telah dikeluarkan dan hasil tersebut merupakan hasil dari perkiraan suatu perusahaan dalam mendapatkan suatu keuntungan ekonomisnya. Dengan metode Economic Value Added (EVA) ini perusahaan dapat meningkatkan nilai perusahaan atau kinerja keuangan perusahaannya karena EVA yang semakin tinggi akan berdampak pada nilai atau kinerja perusahaan yang semakin tinggi terutama dalam harga sahamnya.

Kinerja perusahaan yang baik akan mempengaruhi harga saham, salah satu pengukuran kinerja keuangan selain dengan Economic Value Added (EVA), yaitu Free Cash Flow (FCF). Arus kas bebas merupakan suatu dana yang telah tersisa oleh perusahaan pada saat pembuatan laporan akhir keuangannya. Dana yang tersisa adalah dana yang tersedia setelah perusahaan melakukan hak atau kewajiban atas perusahaannya. Jika perusahaan mempunyai Free cash flow yang semakin tinggi juga akan memberikan dampak baik terhadap harga saham dikarenakan perusahaan tersebut sehat atau dalam kondisi baik.

Berdasarkan penelitian yang relevan atau penelitian yang terdahulu dapat dikaitkan dengan penelitian menurut Dheni Indra Kusuma (2018) yang pada penelitiannya dapat menyimpulkan bahwa Economic Value Added (EVA) mempunyai pengaruh secara signifikan terhadap harga saham sedangkan menurut menurut G.A. Sri Oktaryani, Siti Sofiyah, I Nyoman Nugraha A.P., I Dewa Gede Bisma, I Gede Mandra (2016) pada penelitiannya disimpulkan bahwa Free Cash Flow mempunyai pengaruh secara signifikan terhadap harga saham.

Dengan demikian, dari penjelasan di atas maka dapat disimpulkan mengenai tujuan dari penelitian ini yaitu untuk menguji apakah terdapat pengaruh dari variabel Economic Value Added (EVA) dan Free Cash Flow (FCF) terhadap Stock Price pada perusahaan manufaktur sektor industri barang konsumsi periode 2015-2019.

\section{KAJIAN TEORI}

Teori yang akan digunakan dalam penelitian ini adalah Signalling Theory dan Agency Theory. Menurut Suwardjono (2005), Signalling Theory merupakan sebuah sinyal yang memberikan sebuah informasi yang tentunya sangat dibutuhkan oleh seorang investor dalam melakukan kegiatan penanaman sahamnya pada sebuah perusahaan tersebut. Menurut Jensen dan Meckling (1976) menyatakan tentang Agency Theory atau hubungan keagenan dan dapat didefinisikan sebagai suatu perjanjian antara dua pihak yaitu principal dan agent yang akan mengerjakan sebuah pekerjaan dari pihak principal. Biasanya, masalah yang akan timbul dari sebuah perjanjian ini adalah memiliki perbedaan tujuan antara seorang principal dan agent, pengeluaran biaya yang banyak untuk memeriksa tugas agent, dan risk sharing yang akan menjadi masalah karena terdapat perbedaan antara risiko dari sisi principal dan agent.

\section{Economic Value Added}

Menurut Amin Widjaja Tunggal (2001:1) yang menyatakan bahwa metode Economic Value Added (EVA) di Indonesia didefinisikan sebagai Nilai Tambah Ekonomi (NITAMI) yang berarti suatu sistem untuk mengukur laba ekonomis dalam perusahaan yang mengatakan bahwa kesejahteraan akan muncul dari sebuah perusahaan yang memiliki kemampuan untuk membayar operating cost dan cost of capital. 


\section{Free Cash Flow}

Menurut Damodaran (1997:449) menyatakan bahwa free cash flow adalah tentang arus kas yang didapatkan dari operasi dan pemakaiannya dikontrol oleh pihak manajemen perusahaan tersebut dan manajer memakai free cash flow tersebut untuk membayar proyek, melakukan pembayaran dividen kepada investor, atau menjadikannya sebagai saldo kas.

\section{Stock Price}

Menurut Sartono (2008), harga saham merupakan harga yang terbuat dari permintaan dan penawaran pada saat aktivitas di pasar atau bursa modal. Apabila mengalami permintaan yang berlebih maka harga saham pun akan meningkat, sebaliknya jika mengalami penawaran yang berlebih maka harga saham pun akan menurun.

\section{Penelitian Relevan}

Menurut Ni Made Putri Sri Rahayu dan I Made Dana (2016) pada penelitiannya akan melihat apakah terdapat pengaruh antara variabel Economic Value Added, Market Value Added, dan Likuiditas terhadap harga saham. Dengan demikian, terdapat hasil dari penelitian ini yaitu pada variabel Economic Value Added mempunyai pengaruh secara signifikan dan bersifat negatif pada harga saham sedangkan variabel likuiditas dan Market Value Added mempunyai pengaruh secara signifikan dan bersifat positif pada harga saham.

Menurut William Mingyan Cheung dan Li Jiang (2016), pada penelitiannya tersebut mereka akan meneliti apakah arus kas bebas Jensen atau jensen's free cash flow mempunyai hubungan terhadap kembalinya saham secara lebih. Dengan demikian, penelitian ini dapat disimpulkan bahwa arus kas bebas Jensen atau jensen's free cash flow mempunyai pengaruh yang penting untuk mendapatkan kembalinya saham secara berlebih dan pada penelitian Morck et al. (2000) variasi dari sebuah pengembalian saham sudah menjadi pengukuran yang efektif dalam harga saham.

\section{Kaitan antara Economic Value Added dengan Stock Price}

Menurut Ediningsih dan Nilmawati (2010) menyatakan bahwa EVA memiliki pengaruh yang signifikan dan positif terhadap harga saham dikarenakan jika EVA positif pada suatu perusahaan maka akan memberikan dampak baik pada harga sahamnya. Jika semakin tinggi suatu harga saham tersebut maka akan memberikan kesejahteraan pada investor atau pemegang sahamnya dalam melakukan kegiatan investasi pada perusahaan tersebut.

Menurut Stern Stewart dan Co (1989) yang meneliti mengenai EVA menyimpulkan bahwa EVA terdapat hubungan yang erat dengan perubahan nilai perusahaan pada pasar modal. Jika nilai EVA semakin tinggi maka akan berdampak pada laba yang akan didapatkan pun semakin tinggi. Hal ini membuat seorang investor akan tertarik dalam melakukan keputusan investasi dan berdasarkan penelitian menurut Shidiq (2012) menyatakan bahwa variabel EVA mempunyai pengaruh yang positif terhadap harga saham.

Jika Economic Value Added (EVA) memiliki hasil yang positif maka akan berpengaruh pada harga saham. Jika EVA bersifat positif maka akan memberikan dampak baik pada harga sahamnya. Jika semakin tinggi suatu harga saham tersebut maka akan memberikan kesejahteraan pada investor atau pemegang sahamnya dalam melakukan kegiatan investasi pada perusahaan tersebut dikarenakan laba atau keuntungan yang tinggi sebaliknya jika EVA bersifat negatif 
maka akan memberikan dampak buruk pada harga sahamnya dikarenakan jika EVA menurun maka laba yang akan diterima oleh perusahaan dan investor akan menurun.

H1: Economic Value Added memiliki pengaruh terhadap Stock Price

\section{Kaitan antara Free Cash Flow dengan Stock Price}

Menurut Jensen (1986) dalam Vogt dan Vu (2000) menyimpulkan bahwa free cash flow yang bersifat positif dengan harga saham dari sebuah perusahaan akan terdapat peningkatan dikarenakan pihak manajemen dari sebuah perusahaan akan dituntut untuk menambahkan pembayaran kepada investor dan jika free cash flow yang semakin tinggi maka akan membuat sebuah perusahaan tersebut semakin sehat dan dinyatakan dalam perusahaan yang berada dalam kondisi baik atau aman karena terdapat arus kas bebas yang selalu tersedia.

Menurut Wardani dan Siregar (2009) menyimpulkan pada free cash flow yang mempunyai pengaruh secara signifikan dan positif terhadap nilai pemegang saham, aliran free cash flow yang semakin tinggi maka akan menunjukkan kinerja perusahaan yang semakin tinggi juga. Kemudian dengan aliran free cash flow yang semakin tinggi akan menunjukkan peningkatan kas di masa yang akan datang dan kinerja perusahaan pun akan menambahkan nilai bagi investor yang dapat dilihat dari return yang semakin tinggi dari harga saham, dividen, ataupun laba ditahan untuk kegiatan investasi di masa depan.

Free Cash Flow atau arus kas bebas yang semakin meningkat atau semakin tinggi akan menjadikan sebuah perusahaan tersebut menjadi perusahaan yang sehat atau dinyatakan sebagai perusahaan yang dalam kondisi baik dikarenakan free cash flow atau arus kas bebas yang selalu tersedia dan free cash flow yang semakin tinggi akan membuat kinerja keuangan perusahaan tersebut semakin tinggi dan harga saham pun akan tinggi yang membuat investor akan semakin tertarik.

H2: Free Cash Flow memiliki pengaruh terhadap Stock Price

\section{Kaitan antara Economic Value Added dan Free Cash Flow dengan Stock Price}

Menurut Rosdiana (2011), dengan penelitiannya yang membahas mengenai Cash Dividend, Free Cash Flow, Economic Value Added, dan Return on Assets dapat disimpulkan yaitu secara simultan atau bersama-sama variabel independen tersebut mempunyai pengaruh yang signifikan terhadap harga saham.

Economic Value Added dan Free Cash Flow merupakan komponen yang dapat mempengaruhi harga saham dikarenakan jika EVA bersifat positif dan free cash flow yang memiliki aliran kas yang tinggi (keduanya mengalami peningkatan) maka akan membuat harga saham semakin tinggi. Laba yang didapatkan perusahaan pun akan semakin tinggi dan akan berdampak baik pada investor dengan arus kas yang selalu tersedia oleh perusahaan tersebut.

H3: Economic Value Added dan Free Cash Flow memiliki pengaruh terhadap Stock Price

\section{METODOLOGI}

Subjek dalam penelitian ini adalah perusahaan manufaktur sektor industri barang konsumsi yang terdaftar di Bursa Efek Indonesia (BEI). Objek dalam penelitian ini terdapat dua variabel independen dan satu variabel dependen. Variabel independennya adalah Economic Value Added dan Free Cash Flow sedangkan untuk variabel dependen adalah Stock Price. Berikut merupakan operasionalisasi variabel dalam bentuk tabel sebagai berikut: 


\section{Tabel 1}

\section{Operasionalisasi Variabel}

\begin{tabular}{|c|c|c|c|c|}
\hline Variabel & Indikator & Kode & Skala & Acuan \\
\hline $\begin{array}{c}\text { Economic Value } \\
\text { Added }\end{array}$ & $\begin{array}{r}\text { 1. Weighted Average } \\
\text { Cost of Capital } \\
\text { (WACC) } \\
\text { EVA = Adjusted NOPAT- } \\
\text { Capital Charges }(\text { Capital } \\
\text { Charges = Invested } \\
\text { Capital } \mathrm{x} \text { WACC) }\end{array}$ & EVA1 & Rasio & $\begin{array}{c}\text { Bennett Stewart } \\
\text { (1991) }\end{array}$ \\
\hline Free Cash Flow & $\begin{array}{l}\text { 2. } \mathrm{FCF}=\mathrm{AKO}-\mathrm{WC} \\
\text { - } \mathrm{CAPEX}\end{array}$ & FCF1 & Rasio & $\begin{array}{c}\text { Brigham et.el } \\
(2006: 67)\end{array}$ \\
\hline Stock Price & $\begin{array}{l}\text { 3. Harga saham pada } \\
\text { masa penutupan } \\
\text { (closing price) }\end{array}$ & SP1 & Rasio & Rosdiana (2011) \\
\hline
\end{tabular}

Populasi dalam penelitian ini adalah perusahaan-perusahaan manufaktur sektor industri barang konsumsi. Sampel yang akan digunakan dalam penelitian ini adalah non-probability sampling dengan teknik penelitiannya yaitu purposive sampling. Sampel dalam penelitian ini sebesar 31 perusahaan manufaktur sektor industri barang konsumsi yang telah go-public dan terdaftar di Bursa Efek Indonesia (BEI). Metode yang digunakan untuk penelitian ini adalah metode kuantitatif. Uji statistik yang akan digunakan dalam penelitian ini adalah uji asumsi klasik multikolinearitas, analisis regresi linier berganda, uji hipotesis (uji $\mathrm{F}$ dan uji $\mathrm{T}$ ), dan uji koefisien determinasi.

\section{HASIL ANALISIS DATA}

\section{Uji Multikolinearitas}

Berdasarkan hasil dari Uji Multikolinearitas dan hasil Variance Inflation Factors (VIF) dapat disimpulkan bahwa dari variabel independen yaitu Economic Value Added dan Free Cash Flow mempunyai nilai tolerance lebih besar dari $0,10(0,441658>0,10)$ dan nilai VIF lebih kecil dari 10 (1.242332 < 10). Dengan demikian, tidak terdapat multikolinearitas antar variabel independen pada Perusahaan Manufaktur Sektor Industri Barang Konsumsi Periode 2015-2019.

\section{Hasil Analisis Regresi Linier Berganda}

\section{Tabel 2}

\section{Hasil Analisis Regresi Linier Berganda}

\begin{tabular}{|l|l|l|}
\hline \multicolumn{2}{|l|}{ Dependent Variable: STOCK PRICE } & \\
\hline Method: Panel Least Squares & & \\
\hline Date: $01 / 07 / 21$ Time: $17: 22$ & & \\
\hline Sample: 20152019 & & \\
\hline
\end{tabular}




\begin{tabular}{|c|c|c|c|c|}
\hline \multicolumn{5}{|l|}{ Periods included: 5} \\
\hline \multicolumn{5}{|c|}{ Cross-sections included: 31} \\
\hline \multicolumn{5}{|c|}{ Total panel (balanced) observations: 155} \\
\hline Variable & Coefficient & Std. Error & t-Statistic & Prob. \\
\hline $\mathrm{C}$ & 5788.213 & 371.8247 & 15.56705 & 0.0000 \\
\hline EVA & $6.56 \mathrm{E}-10$ & $2.90 \mathrm{E}-10$ & 2.260862 & 0.0255 \\
\hline $\begin{array}{l}\text { FREE CASH } \\
\text { FLOW }\end{array}$ & $3.24 \mathrm{E}-10$ & $1.46 \mathrm{E}-10$ & 2.220133 & 0.0283 \\
\hline & \multicolumn{2}{|c|}{ Effects Specification } & & \\
\hline \multicolumn{5}{|c|}{ Cross-section fixed (dummy variables) } \\
\hline R-sauared & 0959650 & \multicolumn{2}{|c|}{ Mean dependent var } & 5116090 \\
\hline $\begin{array}{l}\text { Adjusted R- } \\
\text { squared }\end{array}$ & 0.949067 & \multicolumn{2}{|c|}{ S.D. dependent var } & 12403.25 \\
\hline S.E. of regression & 2799.208 & \multicolumn{2}{|c|}{ Akaike info criterion } & 18.89846 \\
\hline Sum squared resid & $9.56 \mathrm{E}+08$ & \multicolumn{2}{|c|}{ Schwarz criterion } & 19.54642 \\
\hline Log likelihood & -1431.631 & \multicolumn{2}{|c|}{ Hannan-Quinn criter. } & 19.16165 \\
\hline F-statistic & 90.67440 & \multicolumn{2}{|c|}{ Durbin-Watson stat } & 1.966071 \\
\hline Prob(F-statistic) & 0.000000 & & & \\
\hline
\end{tabular}

Dari hasil perhitungan analisis regresi linier berganda dalam tabel diatas, maka terdapat persamaannya sebagai berikut:

\section{Stock Price $=5788.213+0.000000000656 \mathrm{EVA}+0.000000000324 \mathrm{FCF}+\varepsilon$}

Dimana,

Nilai konstanta di atas adalah 5788.213 yang berarti jika Economic Value Added dan Free Cash Flow dianggap sebagai konstan, maka Stock Price mempunyai hasil sebesar 5788.213.

Koefisien Regresi Independen dari variabel Economic Value Added mempunyai hasil sebesar 0.000000000656 yang berarti jika variabel independen yang lainnya diasumsikan tetap dan jika Economic Value Added mengalami kenaikan sebesar satu satuan maka Stock Price akan meningkat sebesar 0.000000000656 satuan.

Koefisien Regresi Independen dari variabel Free Cash Flow mempunyai hasil sebesar 0.000000000324 yang berarti jika variabel independen yang lainnya diasumsikan tetap dan jika Free Cash Flow mengalami kenaikan sebesar satu satuan maka Stock Price akan meningkat sebesar 0.000000000324 satuan.

\section{Hasil Uji Hipotesis}

a. Hipotesis pertama

H0 $1: \beta=0$ (Tidak terdapat pengaruh Economic Value Added terhadap Stock Price)

Ha $1: \beta \neq 0$ (Terdapat pengaruh Economic Value Added terhadap Stock Price) 
Berdasarkan hasil pengujian pada tabel dua menunjukkan bahwa nilai probabilitas sebesar 0,0255 lebih kecil dari 0,05 yang berarti variabel Economic Value Added mempunyai pengaruh yang signifikan terhadap Stock Price. Sehingga pada pengujian variabel ini, H0 ditolak dan Ha diterima.

\section{b. Hipotesis kedua}

H0 $2: \beta=0$ (Tidak terdapat pengaruh Free Cash Flow terhadap Stock Price)

Ha $2: \beta \neq 0$ (Terdapat pengaruh Free Cash Flow terhadap Stock Price)

Berdasarkan hasil pengujian pada tabel dua menunjukkan bahwa nilai probabilitas sebesar 0,0283 lebih kecil dari 0,05 yang berarti variabel Free Cash Flow mempunyai pengaruh yang signifikan terhadap Stock Price Sehingga pada pengujian variabel ini, H0 ditolak dan Ha diterima.

\section{c. Hipotesis ketiga}

H0 $3: \beta=0$ (Tidak terdapat pengaruh Economic Value Added dan Free Cash Flow terhadap Stock Price)

Ha $3: \beta \neq 0$ (Terdapat pengaruh Economic Value Added dan Free Cash Flow terhadap Stock Price

Berdasarkan hasil pengujian pada tabel dua menunjukkan bahwa nilai probabilitas sebesar 0,000000 lebih kecil dari 0,05 yang berarti variabel Economic Value Added dan Free Cash Flow secara bersama-sama mempunyai pengaruh yang signifikan terhadap Stock Price. Sehingga pada pengujian variabel ini, $\mathrm{H} 0$ ditolak dan Ha diterima.

\section{Uji Koefisien Determinasi}

Berdasarkan hasil perhitungan pada tabel dua, dapat disimpulkan bahwa nilai dari Adjusted R-Squared sebesar 0.949067 atau sebesar $94.91 \%$ berarti variabel independen (Economic Value Added dan Free Cash Flow) dapat menjelaskan variabel dependen (Stock Price) sebesar $94.91 \%$ kemudian sebesar 5.09\% dijelaskan oleh variabel-variabel lainnya di luar dari penelitian ini.

\section{DISKUSI}

\section{Pengaruh Economic Value Added Terhadap Stock Price}

Jika dilihat dari tabel dua pada uji T (uji signifikansi), variabel Economic Value Added memiliki pengaruh secara signifikan terhadap stock price pada perusahaan manufaktur sektor industri barang konsumsi yang tercatat di Bursa Efek Indonesia periode 2015-2019. Kemudian dapat disimpulkan bahwa hipotesis pertama diterima. Pada hasil analisis regresi linier berganda, terdapat koefisien dari Economic Value Added bersifat positif yang berarti bahwa variabel Economic Value Added memiliki pengaruh yang positif dan signifikan terhadap stock price. Hal ini menunjukkan bahwa Economic Value Added dengan melakukan pengurangan dari laba operasi setelah pajak (Net Operating After Taxes) dengan biaya modal dapat meningkatkan nilai 
perusahaan karena jika EVA memiliki hasil yang positif akan memberikan dampak yang baik juga ke perusahaan tersebut yaitu terhadap harga sahamnya karena jika harga saham semakin tinggi dapat berdampak baik pada seorang investor dengan mendapatkan kesejahteraan untuk kegiatan investasinya di perusahaan tersebut. Hal ini sesuai dengan penelitian dari Stern Stewart dan Co (1989) dan Ediningsih dan Nilmawati (2010) yang mengatakan bahwa variabel Economic Value Added mempunyai pengaruh yang positif dan signifikan terhadap harga saham.

\section{Pengaruh Free Cash Flow Terhadap Stock Price}

Jika dilihat dari tabel dua pada uji T (uji signifikansi), variabel Free Cash Flow memiliki pengaruh secara signifikan terhadap stock price pada perusahaan manufaktur sektor industri barang konsumsi yang tercatat di Bursa Efek Indonesia periode 2015-2019. Kemudian dapat disimpulkan bahwa hipotesis kedua diterima. Pada hasil analisis regresi linier berganda, dapat terdapat koefisien dari Free Cash Flow bersifat positif yang berarti bahwa variabel Free Cash Flow memiliki pengaruh yang positif dan signifikan terhadap stock price. Jika free cash flow memiliki hasil yang tinggi maka akan semakin tinggi harga saham perusahaan tersebut dan kinerja perusahaan tersebut juga akan semakin tinggi yang membuat seorang investor akan tertarik untuk melakukan kegiatan investasi di perusahaan tersebut. Hal ini sesuai dengan penelitian menurut Wardani dan Siregar (2009) dan menurut Jensen (1986) dalam Vogt dan Vu (2000) yang menyimpulkan bahwa free cash flow mempunyai pengaruh signifikan dan positif terhadap harga saham.

\section{Pengaruh Economic Value Added dan Free Cash Flow Terhadap Stock Price}

Jika dilihat dari tabel dua pada uji F (uji bersama-sama), variabel Economic Value Added dan Free Cash Flow secara bersama-sama memiliki pengaruh terhadap stock price dan jika dilihat dari tabel atau hasil dari uji koefisien determinasi, variabel Economic Value Added dan Free Cash Flow dapat menjelaskan sebesar $94.91 \%$ pada Stock Price dan sisanya sebesar 5.09\% dijelaskan oleh variabel-variabel lain di luar penelitian ini. Kemudian dapat disimpulkan bahwa hipotesis ketiga diterima. Komponen dari variabel independen secara simultan dalam penelitian ini merupakan suatu faktor yang tetap harus dilihat oleh investor karena jika EVA bersifat positif dan free cash flow mempunyai arus kas yang tinggi maka akan terdapat peningkatan pada harga saham dan laba yang akan didapatkan sebuah perusahaan akan meningkat dengan arus kas perusahaan yang selalu tersedia yang berarti seorang investor dapat menggunakan EVA dan Free Cash Flow sebagai pengukuran untuk menentukan harga saham (Stock Price). Dengan demikian, dapat disimpulkan bahwa Economic Value Added dan Free Cash Flow mempunyai pengaruh yang signifikan terhadap stock price. Hal ini sesuai dengan penelitian menurut Rosdiana (2011) yang menyimpulkan bahwa variabel-variabel tersebut (Economic Value Added dan Free Cash Flow) Secara Bersama-Sama Mempunyai Pengaruh Secara Signifikan Pada Harga Saham.

\section{PENUTUP}

Pada penelitian ini dapat disimpulkan sebagai berikut:

1. Economic Value Added mempunyai pengaruh yang signifikan dan positif terhadap stock price pada perusahaan manufaktur sektor industri barang konsumsi yang terdaftar di Bursa Efek Indonesia periode 2015-2019. 
2. Free Cash Flow mempunyai pengaruh yang signifikan dan positif terhadap stock price pada perusahaan manufaktur sektor industri barang konsumsi yang terdaftar di Bursa Efek Indonesia periode 2015-2019.

3. Economic Value Added dan Free Cash Flow secara bersama-sama mempunyai pengaruh yang signifikan terhadap stock price pada perusahaan manufaktur sektor industri barang konsumsi yang terdaftar di Bursa Efek Indonesia periode 2015-2019.

Dengan adanya keterbatasan dalam penelitian ini, maka saran yang dapat diberikan dapat disimpulkan sebagai berikut:

1. Sebaiknya pada penelitian selanjutnya menggunakan variabel-variabel independen lainnya untuk mengukur seberapa besar harga saham dan seberapa variabel independen tersebut akan berpengaruh.

2. Sebaiknya pada penelitian selanjutnya dapat memperpanjang periode penelitian supaya hasil yang akan diteliti lebih efektif.

3. Sebaiknya untuk penelitian selanjutnya dapat menggunakan variabel independen yang sama dengan sektor yang berbeda.

\section{DAFTAR PUSTAKA}

Brigham, E.F. and Joel, F.H. (2006). Manajemen Keuangan. pp.67-109. Erlangga. Jakarta.

Cheung, William_Mingyan; Jiang, Li.Review of Quantitative Finance and Accounting; New York Vol. 46, Iss. 1, (Jan 2016): 123-140. DOI:10.1007/s11156-014-0464-2

Damodaran, Aswath. (1997). Corporate Finance Theory and Practice, Jhon \& Wiley and Sons. Inc. New York, Chichester, Toronato, Singapore Weinhein

Ediningsih, Sri Isworo \& Nilmawati. (2010). "EVA dan Beberapa Variabel Fundamental Perusahaan Terhadap Harga Saham”. Jurnal Keuangan dan Perbankan, Vol 14 No. 2 @ Fakultas Ekonomi UPN Veteran Yogyakarta

Jensen, M.C. dan W.H. Meckling. (1976). "Theory of the Firm: Managerial Behaviour, Agency

Cost, and Ownership Structure". Journal of Financial Economic, Vol. 3.

Jensen, M.C. (1986). Agency of Free Cash Flow, Corporate Finance, and Takeovers.American Economics Review, 76, May 1986, pg:232-329

Kusuma, Dheni Indra. (2018) "Pengaruh Rasio Keuangan, Economic Value Added, dan Market Value Added Terhadap Harga Saham Perusahaan Terindeks PEFINDO 25". Jurnal Kajian Bisnis 26 (1): 29-47.

Oktaryani, G.A. Sri, Siti Sofiyah, I Nyoman Nugraha A.P., I Dewa Gede Bisma, I Gede Mandra. (2016) "Pengaruh Free Cash Flow dan Leverage Terhadap Harga Saham dengan Kebijakan Dividen Sebagai Variabel Intervening”. Jurnal Ilmu Manajemen dan Bisnis 1 (2): 1-13.

Rahayu, Ni Made Putri Sri, I Made Dana. (2016) "Pengaruh EVA, MVA, dan Likuiditas Terhadap Harga Saham Pada Perusahaan Food and Beverages”. E-Jurnal Manajemen Unud 5 (1): 443-469.

Rosdiana. (2011). "Analisis Pengaruh Cash Dividend, Free Cash Flow, Return On Asset, dan Economic Value Added Terhadap Harga Saham (Studi Perusahaan Manufaktur di Bursa Efek Indonesia)". Jurnal Ilmu Ekonomi BALANCE 7 (1): 13-19.

Sartono, Agus. (2008). Manajemen Keuangan Teori dan Aplikasi Edisi 8.Yogyakarta:Yogyakarta BPFE 
Shidiq, Niekie Arwiyati (2012), "Pengaruh EVA, Rasio Profitabilitas dan EPS terhadap Harga Saham pada Perusahaan Asuransi yang Terdaftar Di Bursa Efek Indonesia Tahun 20062010", Skripsi, Fakultas Ekonomi Universitas Diponegoro Semarang

Stewart, G. Bennett. (1995), Forgot EPS ROE and ROI. EVA is whatdrives stock price. Harvard Bussines Review, Nov.-Des 199.5, 20.

Suwardjono. (2005). "Teori Akuntansi: Perekayasaan Pelaporan Keuangan”. Edisi Ketiga. BPFE:Yogyakarta.

Tunggal, Amin Widjaja. (2001). Memahami Konsep Economic Value Added (EVA) dan Value Based Management (VBM). Jakarta: Harvarindo

Vogt, Stephen C. And Joseph D. Vu. (2000). Free Cash Flow ang Long-Run Firm Value: Evidence From The Value Line Investment Survey. Journal of Managerial Issues, 12(2), pg:188

Wardani, R.A.Kusuma dan Baldric Siregar. (2009). "Pengaruh Aliran Kas Bebas Terhadap Nilai Pemegang Saham Dengan Set Kesempatan Investasi dan Dividen Sebagai Variabel Moderator". Jurnal Akuntansi dan Manajemen. Vol. 20. No. 3 Desember, hal. 157-174. 